\title{
Caste ontogeny and the distribution of reproductive cells on the combs of Melipona beecheii (Apidae: Meliponini)
}

\author{
Humberto Moo-VALle, José Javier G. QueZADA-EuÁN*, Julio CANTO-MARTíN, \\ Jorge A. GONZALEZ-ACERETO
}

\begin{abstract}
Departamento de Apicultura, Facultad de Medicina Veterinaria y Zootecnia, Universidad Autónoma de Yucatán,
\end{abstract} Apartado Postal 4-116, Mérida, Yucatán 97100, Mexico

(Received 2 June 2003; revised 30 January 2004; accepted 19 February 2004)

\begin{abstract}
The duration of the development phases of workers, males and gynes was studied in Melipona beecheii, an economically important stingless bee species in southern Mexico. We also determined if gynes and male cells were distributed in clusters on the combs as in other Melipona where laying workers exist. The results showed that the total length of development for the workers was $52.72 \pm 1.28$ days. In the case of the gynes and males, it was $50.80( \pm 1.52)$ and $53.43( \pm 1.12)$ days, respectively. We found that clustering of male cells in $M$. beecheii was an uncommon occurrence. We suggest that the main factor explaining the reduced frequency of male cell clusters is that males are not worker-produced in this species, compared to other species of Melipona in which males are worker-produced. Factors related to pollen availability could determine the presence of clustered males in some colonies of this species.
\end{abstract}

stingless bees / Melipona / caste ontogeny / drone production / gyne production

\section{INTRODUCTION}

As in other Hymenoptera, the development of immature stages in Meliponini follows a defined pattern from egg to larva, prepupa, pupa and imago. The duration of the different developmental stages in Meliponini varies between species. In Melipona beecheii Bennett. Darchen and Delage-Darchen (1975), described the five developmental stages only in worker larvae but a detailed account of the duration of each of the ontogenic phases in workers and for reproductives is not yet available for this species.

The Meliponini show contrasting patterns of reproduction compared to other eusocial Hymenoptera (Michener, 1974; Engels et al., 1990; Velthuis, 1997). For instance, stingless bees show a ritualized oviposition process (POP) in which the cells are mass provisioned with larval food. Also, in stingless bees laying workers are more common; they can lay an egg immediately after a cell has been provisioned (before or after the queen has laid her egg) and seal it after they oviposit (Sakagami, 1982). However, there are differences in the rate of worker reproduction between species. In Melipona for instance, laying workers produce the majority of the males in M. subnitida and M. favosa (Koedam, 1999; Koedam et al., 1999; Sommeijer et al., 1999). Interestingly, in those species where reproductive workers exist, the arrangement of male cells can follow a clustered pattern and this could be a result of a temporary domination of workers over the queen

\footnotetext{
*Corresponding author: qeuan@ tunku.uady.mx
} 
(Koedam et al., 1999). Other factors such as the size of pollen stores, the presence of young workers and the characteristics of the cells have been evoked to explain the series of successively produced cells receiving only male-destined eggs (Bezerra, 1995; Koedam, 1999; MooValle et al., 2001). Since in M. beecheii all drones seem to be sons of the queen (Paxton et al., 1999, 2001), a study of the distribution of males on the combs of this species could provide additional clues to other factors that may determine the patterns of distribution of reproductive cells in Melipona.

$M$. beecheii is an economically important stingless bee in southern Mexico. The Maya are the only people that domesticated and cultivated large concentrations of colonies of a stingless bee in the world. Nevertheless, since the European colonization of México, stingless beekeeping has been reduced dramatically and nowadays is near extinction (Quezada-Euán et al., 2001). One of the main obstacles in encouraging modern stingless beekeeping is that little information is available on the basic biology and reproduction of these bees. The objective of this research was to provide a detailed account of the stages of development of $M$. beecheii and patterns of cell arrangement of reproductives on the combs.

\section{MATERIALS AND METHODS}

\subsection{Ontogeny of workers, gynes and drones}

In the first part of this study, the total time of development of the different individuals and castes was established by monitoring 3 colonies in observation hives using video cameras that recorded all activities $24 \mathrm{~h}$ per day. The exact time of oviposition was recorded for each cell. The position of the cells on the comb was marked by transferring the image to a computer were codes for each cell could be added. Additionally, the position of each cell was marked on an acetate sheet were the pattern of the comb under construction was adjusted every day. Fourty five days after the cerumen from all the cells was removed by the workers in the colony, the combs were taken to an incubator were they were maintained at $29-30{ }^{\circ} \mathrm{C}$ and $60 \%$ humidity. Every 3 hours the incubator was checked and the sex and caste of the individuals emerging from the combs was registered as well as the time of their emergence.
An ANOVA was conducted to compare the developmental times of workers, gynes and drones.

In a second approach, cells were marked on combs from 7 colonies using a similar procedure as above, but in this case several cells were opened daily across the developmental stages to have a detailed account of the duration of each phase in accordance to the morphological changes occurred in each type of individual. The different phases were established by means of the morphological categories proposed by Salmah et al. (1996): egg, 3 larval stages, prepupa (thorax, head and abdomen visible but no legs), pupa 1 (body white coloured, legs recognizable), pupa 2 (pigmentation of the eyes, pink), pupa 3 (pigmentation of the ocelli), pupa 4 (pigmentation of wing pads and antennae, wings folded), pupa 5 (colour similar to the adult, wings extended).

\subsection{The distribution of workers, gynes and drones on the combs}

Ten colonies of $M$. beecheii were used in this part of the study. Colonies were selected randomly and therefore had different worker populations and size of the food reserves. Combs containing pupae about to emerge were collected randomly from the center or the top of the brood area. The combs were taken to an artificial incubator kept at the temperature and humidity mentioned in Section 1 and individuals were sexed upon emergence. The position on the comb of the emerging individual and its sex was recorded by taking a picture of the comb with a digital camera and viewing the image on a computer. Each comb was divided into three sections: center, middle and periphery. The number of drones, gynes and workers in those three areas was compared by means of an analysis of proportions using the Fisher's test (Zar, 1984). The relationship between the frequency of each type of individual with the total number of cells on each comb was analysed by means of Pearson's correlations. The same statistic was used to determine the relationship between the proportion of males with gynes and the proportion of males with workers on the combs.

\section{RESULTS}

\subsection{Ontogenic development of workers, gynes and drones}

For the total duration of the development of sexes and castes in $M$. beecheii, 326 cells were surveyed during the period of study: 196 worker cells, 60 gyne cells, and 70 male cells. For the duration of each of the developmental 
Table I. The age and number of days of the different stages of development of the different individuals in $M$. beecheii. The numbers of individuals analysed are in parentheses.

\begin{tabular}{|c|c|c|c|c|c|c|}
\hline \multirow[t]{2}{*}{ Stage } & \multicolumn{2}{|c|}{ Male } & \multicolumn{2}{|c|}{ Gyne } & \multicolumn{2}{|c|}{ Worker } \\
\hline & age & duration & age & duration & age & duration \\
\hline Egg & $1-8(18)$ & 8 & $1-8(18)$ & 8 & $1-8(18)$ & 8 \\
\hline Larva 1 & $9-13(15)$ & 5 & $9-13(15)$ & 5 & $9-13(15)$ & 5 \\
\hline Larva 2 & $14-17(14)$ & 4 & 14-17 (16) & 4 & 14-17 (16) & 4 \\
\hline Larva 3 & $18-27(31)$ & 10 & $18-25(26)$ & 8 & $18-26(28)$ & 9 \\
\hline Prepupa & $28-29(9)$ & 2 & $26-27(6)$ & 2 & $27-28(10)$ & 2 \\
\hline Pupa (white) & $30-32(10)$ & 3 & $28-30(10)$ & 3 & 29-31 (12) & 3 \\
\hline Pupa (pink eyed) & $33-40(29)$ & 8 & $31-36(24)$ & 6 & $32-39(27)$ & 8 \\
\hline Pupa (pigmented ocelli) & $41-46(18)$ & 6 & $37-40(16)$ & 4 & $40-45$ (19) & 6 \\
\hline $\begin{array}{l}\text { Pupa (wing pads and } \\
\text { antennae pigmented- } \\
\text { wings folded) }\end{array}$ & $47-49(12)$ & 3 & $41-44(13)$ & 4 & $46-48(12)$ & 3 \\
\hline $\begin{array}{l}\text { Pupa (darkened } \\
\text { body- wings extended) }\end{array}$ & $50-55(19)$ & 6 & $45-51(20)$ & 7 & $49-53(14)$ & 5 \\
\hline $\begin{array}{l}\text { Average days } \\
\text { of development }\end{array}$ & \multicolumn{2}{|c|}{$\begin{array}{c}53.48 \text { a } \\
( \pm 1.12) a\end{array}$} & \multicolumn{2}{|c|}{$\begin{array}{c}50.80 \\
(1.52) b\end{array}$} & \multicolumn{2}{|c|}{$\begin{array}{c}52.72 \\
(1.28) \mathrm{c}\end{array}$} \\
\hline
\end{tabular}

stages, a total of 510 individuals were surveyed: 171 workers, 164 gynes, and 175 males. The results of the total ontogenic development and the duration of the different stages from egg to emergence for the 3 types of individuals are presented in Table I. There were statistical differences among the three types of individuals $(\mathrm{F}=27.63 \mathrm{df}=2,324 ; P=0001)$. The total development for the workers was $52.72 \pm$ 1.28 days. The gynes developed faster than the workers $(50.8 \pm 1.52)$ and the males slower $(53.48 \pm 1.12)$ (Tab. I). The main differences in the development of the three castes were in the duration of the 3rd larval instar and the pupal stages 2 to 5 (Tab. I). The total duration of the larval stages for the workers was 18 days $( \pm 1.3)$, for the gynes $17( \pm 1.1)$ and for the males $19( \pm 1.18)$. The total pupal stages for the workers as 25 days $( \pm 1.23)$, whilst the males lasted $26( \pm 1.27)$ and the gynes $24( \pm 1.14)$.

We observed that workers emerged from their cells by cutting open the top with their mandibles in an irregular pattern and in the process were assisted by other workers. The workers were slow leaving the cell, and soon after they received food from an older worker. The males needed more assistance from older workers for coming out of their cells compared to workers. In contrast with workers and drones, gynes cut off the top of the cell by themselves leaving a neat circular top. Gynes also quickly left their cells and the comb area escaping and hiding away from workers that tried to catch them. A number of gynes were nevertheless killed immediately after emerging from their cells whilst others remained in the colony for a few days before being executed too.

\subsection{The distribution of workers, gynes and drones on the combs}

The proportion of male cells was, on average, $10.2 \%$ in the center of the combs, $8.5 \%$ in the middle and $4.6 \%$ in the periphery (Tab. II). In $M$. beecheii, males were found more frequently in the center and the middle section of the combs. However, in most colonies, male cells were equally distributed among the three sections of the comb (Tab. II). Only in colonies 1 and 4 (20\% of the studied colonies) were the males significantly concentrated in the center (Fig. 1).

For gyne cells, the proportions were similar between the center (5\%) middle (3.4) and periphery of the combs $(3.4 \%)$ (Tab. II). At the individual colony level, we found no statistical 
Table II. Comparison of the percentage of cells containing males, gynes and workers in the center (C), Middle (M) and the periphery $(\mathrm{P})$ of combs in $10 \mathrm{M}$. beecheii colonies. Within each type of individual, the different letters among $\mathrm{C}, \mathrm{M}$ and $\mathrm{P}$ denote statistical differences at $p<0.01$. $\mathrm{EP}=$ estimated worker population of colonies.

\begin{tabular}{|c|c|c|c|c|c|c|c|c|c|c|c|}
\hline \multirow[t]{2}{*}{ COLONY } & \multirow[t]{2}{*}{$\mathrm{EP}$} & \multirow{2}{*}{$\begin{array}{l}\text { Cells/ } \\
\text { comb }\end{array}$} & \multicolumn{3}{|c|}{ Workers } & \multicolumn{3}{|c|}{ Males } & \multicolumn{3}{|c|}{ Gynes } \\
\hline & & & $\mathrm{C}$ & M & $\mathrm{P}$ & $\mathrm{C}$ & M & $\mathrm{P}$ & $\mathrm{C}$ & M & $\mathrm{P}$ \\
\hline 1 & 500 & 258 & $0.069 \mathrm{a}$ & $0.182 b$ & $0.240 \mathrm{~b}$ & $0.224 \mathrm{a}$ & $0.127 \mathrm{~b}$ & $0.042 \mathrm{c}$ & $0.038 \mathrm{a}$ & $0.023 \mathrm{a}$ & $0.050 \mathrm{a}$ \\
\hline 2 & 800 & 66 & $0.212 \mathrm{a}$ & $0.181 \mathrm{a}$ & $0.257 \mathrm{a}$ & $0.015 \mathrm{a}$ & $0.075 \mathrm{a}$ & $0.060 \mathrm{a}$ & $0.181 \mathrm{a}$ & $0.075 \mathrm{ab}$ & $0.015 b$ \\
\hline 3 & 400 & 63 & $0.269 \mathrm{a}$ & $0.301 \mathrm{a}$ & $0.301 \mathrm{a}$ & $0.063 \mathrm{a}$ & $0.031 \mathrm{a}$ & $0.031 \mathrm{a}$ & 0 & 0 & 0 \\
\hline 4 & 450 & 219 & $0.136 \mathrm{a}$ & $0.237 b$ & $0.237 \mathrm{~b}$ & $0.155 \mathrm{a}$ & $0.073 b$ & $0.022 b$ & $0.041 \mathrm{a}$ & $0.022 \mathrm{a}$ & $0.073 \mathrm{a}$ \\
\hline 5 & 300 & 179 & $0.173 \mathrm{a}$ & $0.229 a$ & $0.279 a$ & $0.134 \mathrm{a}$ & $0.089 \mathrm{ab}$ & $0.039 \mathrm{~b}$ & $0.022 \mathrm{a}$ & $0.0016 \mathrm{a}$ & $0.016 \mathrm{a}$ \\
\hline 6 & 300 & 100 & $0.190 \mathrm{a}$ & $0.260 \mathrm{a}$ & $0.270 \mathrm{a}$ & $0.120 \mathrm{a}$ & $0.060 \mathrm{a}$ & $0.050 \mathrm{a}$ & $0.020 \mathrm{a}$ & $0.010 \mathrm{a}$ & $0.020 \mathrm{a}$ \\
\hline 7 & 550 & 79 & $0.240 \mathrm{a}$ & $0.240 \mathrm{a}$ & $0.240 \mathrm{a}$ & $0.088 \mathrm{a}$ & $0.101 \mathrm{a}$ & $0.025 \mathrm{a}$ & $0.025 \mathrm{a}$ & $0.012 \mathrm{a}$ & $0.025 \mathrm{a}$ \\
\hline 8 & 850 & 162 & $0.271 \mathrm{a}$ & $0.234 \mathrm{a}$ & $0.277 \mathrm{a}$ & $0.006 \mathrm{a}$ & $0.006 \mathrm{a}$ & $0.006 \mathrm{a}$ & $0.055 \mathrm{a}$ & $0.037 \mathrm{a}$ & $0.049 \mathrm{a}$ \\
\hline 9 & 400 & 55 & $0.163 \mathrm{a}$ & $0.072 \mathrm{a}$ & $0.181 \mathrm{a}$ & $0.090 \mathrm{a}$ & $0.127 \mathrm{a}$ & $0.109 \mathrm{a}$ & $0.072 \mathrm{a}$ & $0.127 \mathrm{a}$ & $0.054 \mathrm{a}$ \\
\hline 10 & 400 & 64 & $0.156 \mathrm{a}$ & $0.187 \mathrm{a}$ & $0.203 \mathrm{a}$ & $0.125 \mathrm{a}$ & $0.109 \mathrm{a}$ & $0.078 \mathrm{a}$ & $0.046 \mathrm{a}$ & $0.031 \mathrm{a}$ & $0.062 \mathrm{a}$ \\
\hline Average & 495 & 124.5 & $0.188 \mathrm{a}$ & $0.212 b$ & $0.248 b$ & $0.102 \mathrm{a}$ & $0.085 \mathrm{a}$ & $0.046 \mathrm{~b}$ & $0.050 \mathrm{a}$ & $0.034 \mathrm{a}$ & $0.036 \mathrm{a}$ \\
\hline SD & 190.7 & 74.1 & 0.062 & 0.006 & 0.036 & 0.065 & 0.039 & 0.029 & 0.050 & 0.039 & 0.024 \\
\hline
\end{tabular}

differences in the distribution of gyne cells between areas of the comb in 9 colonies (except for colony 2 , in which gynes were more frequent in the center of the comb) (Tab. II). There was no significant correlation between male and gyne cells on the combs $(r=-0.06$, Fig. 2$)$ and we found no evidence of clusters of cells containing gynes in all colonies (Tab. II).

Worker cells were more frequently distributed in the periphery (25\%) and less frequently in the center of the combs (19\%). There was a significant negative correlation between male and worker cells on the combs $(\mathrm{y}=-0.711 \mathrm{x}+$ $0.234 ; \mathrm{r}=-0.815 ; P=0.0001$, Fig. 3). This finding was also supported by the fact that at the individual colony level, colonies 1 and 4 had significantly more worker cells in the middle and periphery of the comb (Tab. II and Fig. 1).

There was no relationship between the number of cells in the comb with the number of male cells $(\mathrm{y}=0.0004 \mathrm{x}+0.184 ; \mathrm{r}=0.243$; $P=0.248)$; gyne cells $(\mathrm{y}=-0.0002 \mathrm{x}+0.148$; $\mathrm{r}=0.181 ; P=0.308)$ or worker's $(\mathrm{y}=-0.0003 \mathrm{x}+$ $0.686 \mathrm{r}=-0.156 ; P=0.332$ ).

\section{DISCUSSION}

\subsection{Ontogenic development of workers, gynes and drones}

Few studies are available to date on the incubation period of different stingless bee species and none were available for any of the Mexican species. In our study, we determined the ontogenic development of the different individuals in $M$. beecheii. The general results were in agreement with former studies in this taxa revealing slower times of development for stingless bees compared with $A$. mellifera (Kerr, 1948; Nates-Parra et al., 1989; Salmah et al., 1996). The total ontogenic development of $M$. beecheii workers was 2.4 times that of the workers of A. mellifera (21 days; Winston, 1987). However, it was also slower compared with other Melipona since it was 1.5 longer than the development of workers M. quadrifasciata (35 days; Cruz-Landim, 1966). On the other hand, it was remarkably similar to that of workers of M. scutellaris (49 days), the main difference with the latter being in the total duration 
Colony 1

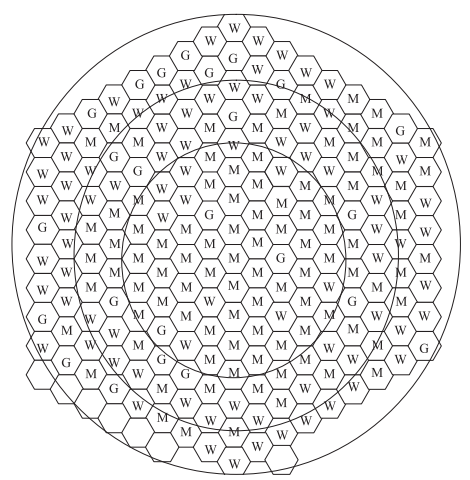

Colony 5

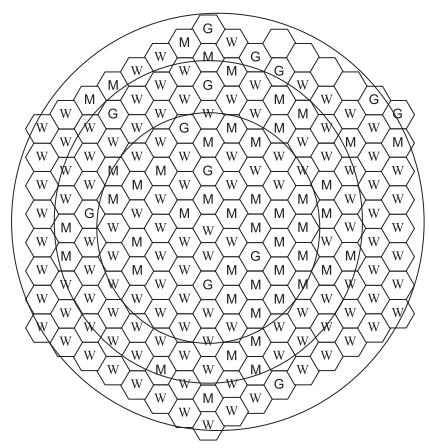

Figure 1. An example of the distribution of workers, males and gynes in colony 1 (where male cells where significantly clustered) and colony 5 (where there was no male clustering). The center, middle and periphery of the combs are indicated by concentric circles. $\mathrm{W}=$ worker, $\mathrm{M}=$ male, $\mathrm{G}=$ gyne.

of the larval stages which is 3 days longer in $M$. beecheii (Almeida, 1974). Compared with the few Trigonini species where data are available, the development of workers of $M$. beecheii was similar with the workers of the Asian $T$. minangkabau (42 days); T. moorei (46.5 days) and T. itama (46.5 days) (Salmah et al., 1996). Compared with neotropical T. angustula, it was 1.5 times slower (Nates-Parra et al., 1989).

The differences we found between the development of individuals in $M$. beecheii and other eusocial bee species can be explained by several factors. The differences between Meliponini and Apini may depend on the characteristics of the larval food in both taxa (Camargo, 1972; Hartfelder and Engels, 1989). It seems that the digestibility of the larval food in A. mellifera is above $90 \%$ because of its low

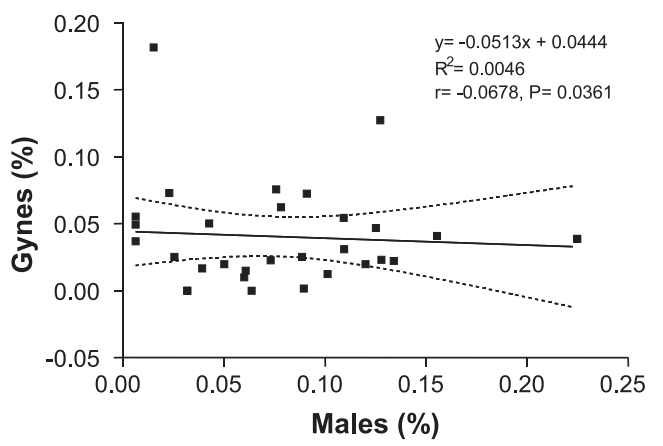

Figure 2. The correlation between the proportion of male and gyne cells found on the combs of $M$. beecheii.

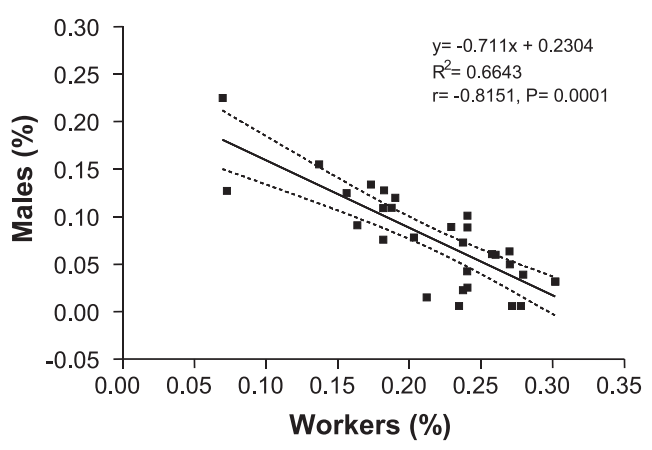

Figure 3. The correlation between the proportion of male and worker cells found on the combs of $M$. becheii.

pollen fraction relative to glandular secretions (Webster and Peng, 1988; Hartfelder and Engels, 1989). The glandular fraction of larval food in Meliponini is comparatively lower and this may cause the larvae to take longer to digest it. Thus, the availability of nutrients in their food may delay the development of the Meliponini larvae compared to the larvae of Apini.

The differences in the development between $M$. beecheii and other stingless bees may involve additional factors such as the fluctuation of temperature within the nest. There is a wide range in thermoregulation capacities among stingless bees. In species where the temperature within the brood area is maintained within narrow limits, such as M. quadrifasciata (Kerr, 1948; Roubik and Peralta, 1983) and T. angustula (Nates-Parra et al., 1989), the data 
show that the development of the individuals is faster. In contrast, there is a comparatively wider fluctuation of the temperature within the brood area of $M$. beecheii (Moo-Valle et al., 2000). We think this explains the slower developmental times that were obtained for this species. Since the pupae in the last part of our study developed under controlled conditions there may have been a slight difference from individuals developing in natural conditions during the last instars when combs were taken to the incubator.

At the individual level, it is interesting to note that in $M$. beecheii, the gynes developed faster than the workers and the workers developed faster than the males, similar to what occurs in Apini. In Apini, drone larval food has a higher proportion of pollen (Winston, 1987) and therefore has less glandular contents compared to queen and worker food. Moreover, the males are much larger than the workers and may need longer development times. In Melipona, there is no detailed information on the nutritional characteristics of the larval food that the different sexes and castes receive, although the queens seem to receive less food compared to the workers (Van Veen, 1999). Thus, an explanation for the differences in development times between sexes and castes in Melipona may depend on the quantity and quality of the larval food they receive (Kerr, 1950; Darchen and Delage-Darchen, 1977) similar to what occurs in A. mellifera (Winston, 1987).

\subsection{The distribution of workers, gynes and drones on the combs}

Regarding the distribution of male and gyne cells in $M$. beecheii, we found the overall tendency was that male cells were concentrated equally in the center and the middle of the combs, in contrast to what has been reported in other Melipona species (Koedam et al., 1999). However, at the individual colony level there were differences in the distribution of male cells in the three sections of the comb in two colonies. It also seems that such a pattern was not related to the population of the colony indicating that it is perhaps a consequence of the cyclical construction of cells proposed for Melipona (Koedam, 1999).

In M. subnitida and M. favosa, two species where the males can be produced by workers, male cells are frequently found clustered (Koedam, 1999; Koedam et al., 1999). A temporary "workerdominance" has been proposed to explain the clustering of males in $M$. subnitida and $M$. favosa (Chinh et al., 2003) and the reproductive laying worker behaviour is cyclical resulting in periods of worker male production (Sommeijer et al., 2003). The reduced frequency of male cell clustering in $M$. beecheii, a species where all males are queen produced (Paxton et al., 2001), give support to the hypothesis that the reproductive conflict between the queen and workers seem to be one of the main factors related to the distribution of male cells in other Melipona species where reproductive workers are common. Therefore, the clustering of male cells found in two $M$. beecheii colonies suggests that in this species other factors may be involved.

Large pollen reserves determine the production of males in $M$. beecheii and may be a factor influencing the distribution of male cells on combs (Moo-Valle et al., 2001). In a situation when larval food provisioners have access to large pollen stores, the cells in the center of the comb may receive more food, creating a pattern of clustered cells with higher quantities of pollen in the central parts of some combs where male eggs are laid by the queen. As the comb expands clustering will be reduced in areas of the comb away from the center.

On the other hand, gyne production compared with drone production in Melipona, does not requiere that colonies have such large pollen stores (Moo-Valle et al., 2001). Firstly, because gynes are likely to develop with smaller quantities of larval food due to its reduced body size (Ratnieks, 2001) and secondly, because there is a genetic component of caste determination (Velthuis and Sommeijer, 1991). Thus, gyne cells in Melipona combs can be evenly distributed compared to male cells (Koedam, 1999; Koedam et al., 1999).

\section{ACKNOWLEDGEMENTS}

We thank CONACYT-SISIERRA (Rescate de meliponicultura en la península Yucatán, desarrollo de colmenas racionales para especies nativas y su aplicación para la polinización de cultivos) and YUCATAN-PRODUCE (Manejo tecnificado de abejas natives sin aguijón y su uso en la polinización de cultivos) for supporting this study. 
Résumé - Ontogenèse des castes et répartition des cellules de reproduction sur les rayons de Melipona beecheii (Apidae : Meliponini). Nous avons étudié la durée des phases de développement des ouvrières, des mâles et des femelles de Melipona beecheii Bennett, abeille sans aiguillon d'importance économique dans le sud du Mexique. La position exacte et le moment de la ponte ont été enregistrés pour chaque cellule dans trois colonies et le sexe et la caste des individus qui ont émergé des rayons, ainsi que le moment de leur émergence, ont été notés. Dans un autre groupe de sept colonies, un relevé détaillé de la durée de chaque phase de développement a été fait à l'aide de la technique qui consiste à ouvrir les cellules chaque jour et à noter les changements morphologiques des trois types d'individus. Nous avons séparé les différentes phases selon les catégories morphologiques de Salmah et al. (1996). Dix colonies de M. beecheii ont été utilisées afin de déterminer si les cellules de mâles étaient réparties en agrégats sur les rayons comme chez d'autres espèces de Melipona où existent des ouvrières pondeuses. L'agrégat de cellules de mâles a été déterminé par enregistrement de la position sur le rayon de l'individu émergeant. Chaque rayon a été divisé en trois sections : le centre, le milieu et la périphérie et le nombre de mâles, de femelles et d'ouvrières dans ces trois zones a été comparé. Les résultats montrent que la durée totale du développement pour les ouvrières était de $52,72 \pm 1,28 \mathrm{j}$. Dans le cas des femelles et des mâles, il était de 50,80 $( \pm 1,52)$ et 53,48 $( \pm 1,12) \mathrm{j}$, respectivement (Tab. I). Les différences entre les trois types d'individus sont statistiquement significatives $(\mathrm{F}=27,63 \mathrm{df}=2,324)$. La proportion de cellules de mâles était en moyenne de $10,2 \%$ au centre des rayons, de $8,5 \%$ au milieu et de $4,6 \%$ à la périphérie (Tab. II). Selon nos résultats l'agrégation des cellules de mâles chez $M$. beecheii est peu courant. Il n'y avait pas de corrélation significative entre les cellules de mâles et les cellules de femelles sur les rayons $(r=-0,06$; Fig. 2$)$ et l'agrégation de cellules de femelles n'a pu être mise en évidence dans aucune des colonies (Tab. II). Nous en concluons que le principal facteur qui explique la faible fréquence des agrégats de cellules de mâles est que les mâles ne sont pas produits par les ouvrières chez cette espèce, contrairement aux autres espèces de Melipona où ils le sont. Des facteurs liés à la disponibilité de pollen pourrait déterminer la présence d'agrégats de mâles dans certaines colonies de cette espèce (Fig. 1).

Melipona / abeille sans aiguillon / ontogneèse / caste / production de mâles / production de femelles

Zusammenfassung - Entwicklungsstadien der Kasten und Verteilung der Geschlechtstiere produzierenden Zellen auf den Waben von Melipona beecheii (Apidae: Meliponini). Die vorliegende Studie untersuchte die Dauer der Entwicklungsphasen von Arbeiterinnen, Männchen und
Königinnen der im südlichen Mexiko vorkommenden und ökonomisch wichtigen stachellosen Biene Melipona beecheii. Die genaue Position und der Zeitpunkt der Eiablage wurde für jede Zelle in drei Völkern registriert und dann zum Zeitpunkt des Schlüpfens mit dem Geschlecht, beziehungsweise der Kaste abgeglichen. In weiteren sieben Völkern wurde die genaue Dauer der einzelnen Ontogenesephasen untersucht, indem die Zellen täglich geöffnet und die morphologischen Veränderungen in den drei Phänotypen entsprechend der von Salmah et al. (1996) aufgestellten Kriterien registriert wurden. In zehn Kolonien von $M$. beecheii wurde untersucht, ob Zellen mit männlicher Brut ebenso in Gruppen über die Brutwabe verteilt sind, wie dies in Melipona-Arten auftritt, bei denen eierlegende Arbeiterinnen vorkommen. Zur Bestimmung der Gruppierung der Brutzellen mit Geschlechtstieren wurde ihre Position auf der Wabe beim Schlüpfen der Männchen, Arbeiterinnen oder Königinnen notiert. Jede Wabe wurde dabei in drei Zonen unterteilt, eine innere, eine mittlere und eine äussere Zone. Für Arbeiterinnen ermittelten wir eine Gesamtdauer der Entwicklung von 52,72 \pm 1,28 Tagen. Bei Königinnen betrug die Entwicklungsdauer 50,80 \pm 1,52 und bei Männchen 53,48 \pm 1,12 Tage (Tab. I). Die Dauer der Gesamtentwicklung der drei Phänotypen unterschied sich dabei signifikant $(F=27,63 \mathrm{df}=2,324)$. Der Anteil an Brutzellen mit Männchen betrug im Durchschnitt $10,2 \%$ für die innere Wabenzone und $8,5 \%$, bzw. 4,6\% für die mittlere und die äussere Zone. Eine Gruppierung von männlichen Brutzellen war nur in seltenen Fällen erkennbar. Wir konnten keine signifikante Korrelation zwischen der Position der Brutzellen mit Männchen- und der mit Königinnen feststellen $(\mathrm{r}=-0,06 ;$ Abb. 2), und wir fanden auch keine Anhaltspunkte für eine Gruppierung von Brutzellen mit Königinnen auf den Brutwaben (Tab. II). Wir schliessen daraus, dass die fehlende Gruppierung von Brutzellen mit Männchen vermutlich darin bedingt liegt, dass bei $M$. beecheii die Männchen nicht wie bei anderen Melipona-Arten von Arbeiterinnen produziert werden. Faktoren wie die Verfügbarkeit von Pollen könnten in einigen Fällen allerdings zu einem gruppierten Auftreten von Männchen geführt haben (Abb. 1).

Stachellose Bienen / Melipona / Kastenentwicklung / Drohnenproduktion

\section{REFERENCES}

Almeida M.G. de (1974) Ciclo de vida da abelha Melipona scutellaris em condicoes semi-artificiais, Anais do $3^{\circ}$ Congr. Bras. Apic., Piracicaba, Brasil, pp. 171-178.

Bezerra J.M.D. (1995) aspectos da reproducao de Melipona quadrifasciata (Hymenoptera, Apidae), Master-thesis, Vicosa, Minais Gerais, Brasil.

Camargo C.A. de (1972) Aspectos da reproducao dos Apideos Sociais, Disertación para Magister, U. Sao Paulo, Ribeirao Preto, Brasil. 
Chinh T.X., Grob G.B.J., Meeuwsen F.J.A.J., Sommeijer M.J.(2003) Patterns of male production in the stingless bee Melipona favosa (Apidae, Meliponini), Apidologie 34, 161-170.

Cruz-Landim D. da (1966) Alguns dados sobre o desenvolvimento de Melipona (Hym. Apoidea), Rev. Bras. Biol. 26, 165-174.

Darchen R., Delage-Darchen B. (1975) Contribution a l'étude d'une abeille du Mexique Melipona beecheii B. (Hymenoptère : Apidae), Apidologie 6, 295-339.

Darchen R., Delage-Darchen B. (1977) Sur le determinisme des caste chez les Meliponines (Hymenoptères : Apides), Bull. Biol. Fr. Belg. 111, 91-109.

Engels W., Imperatriz-Fonseca V.L. (1990) Caste development, reproductive strategies and control of fertility in honey bees and stingless bees, in: Engels W. (Ed.), Social Insects: An Evolutionary Approach to castes and Reproduction, SpringerVerlag Berlin Heidelberg, Germany, pp. 168-230.

Hartfelder K., Engels W. (1989) The composition of larval foot in stingless bees: Evaluating nutritional balance by Chemosystematic methods, Insectes Soc. 36, 1-14.

Kerr W.E. (1948) Estudo sobre o genero Melipona, Anais da Esc. Sup. de Agric. Luis de Queiroz 5, $181-226$.

Kerr W.E. (1950) Genetic determination of castes in the genus Melipona, Genetics 35, 143-152.

Koedam D. (1999) Production of queens, workers and males in the stingless bee Melipona favosa (Apidae: Meliponinae): Patterns in time and space, Neth. J. Zool. 49, 289-302.

Koedam D., Contrera F.A.L., Imperatriz-Fonseca V.L. (1999) Clustered male production by workers in the stingless bee Melipona subnitida Ducke (Apidae, Meliponinae), Insectes Soc. 46, 387-391.

Michener C.D. (1974) The social behaviour of the bees: a comparative study, Harvard Univ. Press, Cambridge.

Moo-Valle H., Quezada-Euán J.J.G., Navarro-Alberto J., Rodriguez-Carvajal L.A. (2000) Patterns of intranidal temperature fluctuation for Melipona beecheii colonies in natural nesting cavities, J. Apic. Res. 39, 3-7.

Moo-Valle H., Quezada-Euán J.J.G., Wenseleers T. (2001) The effect food reserves on the production of sexual offpring in the stingless bee Melipona beecheii (Apidae: Meliponini), Insectes Soc. 48, 398-403.

Nates-Parra G., Villa A., Vergara B. (1989) Ciclo de desarrollo de Trigona (Tetragonisca) angustula, Latreille 1811 (Hymenoptera, Trigonini), Acta Biol. Colom. 1, 91-98.

Paxton R.J., Weißschuh N., Engels W., Hartfelder K., Quezada-Euán J.J.G. (1999) Not only single mating in stinglees bees, Naturwissenschaften 86, 143-146.

Paxton R.J., Ruhnke H., Shah, M., Bego L.R., QuezadaEuán J.J.G., Ratnieks F.L.W. (2001) Social evolution in stingless bees: are the workers or is the queen in control of male parentage? in: II Semi- nario mexicano sobre abejas sin aguijón, Mérida,Yucatán México 9-10th November 2001, pp. 104-107.

Quezada-Euán J.J.G., May-Itzá W.J., GonzálezAcereto J.A. (2001) Meliponi culture in Mexico: problems and perspective for development, Bee World 82, 160-167.

Ratnieks F.L.W. (2001) Heirs and spares: caste conflict and excess queen production in Melipona bees, Behav. Ecol. Sociobiol. 50, 467-473.

Roubik D.W., Peralta F.J.A. (1983) Thermodynamics in nests of two Melipona species in Brasil, Acta Amaz. 13, 453-466.

Sakagami S.F. (1982) Stingless bees, in: Hermann H.R. (Ed.), Social Insects, Vol. III, Academic Press, New York, p. 3, 361-423.

Salmah S., Inoue T., Sakagami S.F. (1996) Incubation period and post-emergence pigmentation in the sumatran stingless bee Trigona (Heterotrigona) itama (Apidae, Meliponinae), Jpn J. Entomol. 64, 401-411.

Sommeijer M.J., de Bruijn L.L.M., Van de Guchte C. (1985) The social food-flow within the colony of a stingless bee Melipona favosa (F.), Behaviour 92, 39-58.

Sommeijer M.J., Chinh T.X., Meeuwsen F.J.A.J. (1999) Behavioural data on the production of males by workers in the stingless bee Melipona favosa (Apidae, Meliponinae), Insectes Soc. 46, 92-93.

Sommeijer M.J., de Bruijn L.L.M., Meeuwsen F.J.A.J., Martens E.P. (2003) Natural patterns of caste and sex allocation in the stingless bees Melipona favosa and $M$. trinitatis related to worker behaviour, Insectes Soc. 50, 38-44.

Van Veen J.W. (1999) Cell provisioning and oviposition in Melipona beecheii (Apidae, Meliponini), with a note on caste determination, in: van Veen J.W. (Ed.), Colony Reproduction in Stingless Bees, Litografia e Imprenta Lil, S.A., San José, Costa Rica, pp. 65-76

Velthuis H. (1997) The biology of stingless bees, Dept. Ethology and Socio-ecology, Utrecht University, The Netherlands.

Velthuis H. (1997) The biology of stingless bees, Dept. Ethology and Socio-ecology, Utrecht University, The Netherlands.

Velthuis H.H.W., Sommeijer M.J. (1991) Roles of Morphogenetic Hormones in Caste Polymorphism in Stingless Bees, in: Gupta A.P. (Ed.), Morphogenetic Hormones of Arthropodes, Rutgers Univ. Press, New Brunswick, USA, pp. 346-383.

Webster T.C., Peng Y.S. (1988) The evolution of foodproducing glands in eusocial bees (Apoidea, Hymenoptera), J. Evol. Biol. 2, 165-176.

Winston M. (1987) The biology of the honey bee, Harvard Univ. Press, Cambridge, Massachusetts, London, England.

Zar J.H. (1984) Biostatistical analysis, Prentice Hall, Englewood Cliff, New Jersey, 2nd ed. 